\title{
KEBIJAKAN FORMULASI SANKSI TINDAKAN BAGI PENGGUNA DALAM TINDAK PIDANA NARKOTIKA
}

\author{
Hatarto Pakpahan
}

Fakultas Hukum Universitas Merdeka

J1. Terusan Raya Dieng 62-64 Malang

Email: pakpahan_anto@yahoo.com

\begin{abstract}
Drug abusers to yourself (addicts) basically get bail rehabilitation but the criminal provisions of Article 127 of Law Repulik Indonesian law number 35 of 2009 on Narcotics with the threat of imprisonment. In the practice of law enforcement when someone is abusing narcotics for yourself also applied criminal Article 111 and Article 112 or Article 114 because even meet the elements of: have, save,master, and or buy. This paper aims to find, test and analyze whether the sanctions measures can be used as an alternative form of sanctions, and the sanctions that can be used as an alternative sanction in the reformulation of narcotic crime in the future . This paper is made based on the results of research using the normative with Statute Approach, Case Approach, Conceptual Approach and Comparative Approach. The results showed that the drug abusers themselves should only be penalized in the form of medical rehabilitation measures and social rehabilitation for drug abusers are victims as well as sick people who should get treatment so it can recover. Although his actions comply with Article 111 and Article 112 or Article 114 even if the mens rea is to be used for the actors themselves to be in rehab.
\end{abstract}

Key words: abusers, victims, narcotics, rehabilitation

\begin{abstract}
Abstrak
Penyalah guna narkotika bagi diri sendiri (pecandu)pada dasarnya mendapatkan jaminan rehabilitasi akan tetapi dalam ketentuan pidana pasal 127 undang undang no 35 tahun 2009 tentang Narkotika dengan ancaman pidana penjara. Dalam praktek ketika seseorang yang menyalahgunakan narkotika bagi diri sendiri juga diterapkan pidana pasal 111 dan atau pasal 112 bahkan pasal 114 karena juga memenuhi unsur "memiliki", "menyimpan", "menguasai" dan atau "membeli". Tulisan ini bertujuan untuk mengetahui, menguji dan menganalisis apakah sanksi tindakan dapat dijadikan sebagai alternatif sanksi serta bentuk sanksi tindakan yang dapat dijadikan sebagai sanksi alternatif dalam reformulasi tindak pidana narkotika dimasa mendatang. Tulisan ini dibuat berdasarkan hasil penelitian normatif yang menggunakan pendekatan Statute Approach, case Approach, Conceptual approach dan komparatif Approach.Hasil penelitian menunjukkan bahwa Penyalah guna narkotika bagi diri harusnya hanya dikenakan sanksi tindakan berupa rehabilitasi medis dan rehabilitasi sosial karena penyalah guna narkotika adalah korban sekaligus sebagai orang sakit yang harus mendapatkan pengobatan sehingga dapat pulih kembali. Sekalipun perbuatannya memenuhi pasal 111 dan atau pasal 112 maupun pasal 114 jika sikap bathin (mens rea) pelaku adalah untuk digunakan bagi diri sendiri harus di rehabilitasi.
\end{abstract}

Kata kunci: penyalah guna, korban, narkotika, rehabilitasi 


\section{Latar Belakang}

Saat ini ada tiga jenis keadaan darurat (bentuk penjajahan) yang dihadapi Indonesia yang sangat berbahaya dan bahkan mengancam masa depan dan generasi bangsa ini, yaitu penyalahgunaan narkotika, pornografi dan juga tindakan senang mengimport segala sesuatu dari luar negeri. Tiga keadaan ini merupakan suatu fenomena yang saat ini sudah kita anggap lazim akan tetapi dampaknya untuk generasi maupun masa depan bangsa indonesia sangat besar karena terutama pemuda sebagai generasi bangsa yang kerapkali sebagai korban yang terlena menikmatinya sehingga lalai dalam melaksanakan tugas dan kewajibannya sebagai pemuda dan generasi penerus bangsa. Satu dari tiga keadaan tersebut yang sekaligus termasuk dalam kategori tindak pidana adalah penyalahgunaan narkotika. Kejahatan narkotika merupakan jenis kejahatan yang cukup serius yang mengancam masa depan generasi bangsa, untuk itu perlu mendapatkan penangan yang tepat dan serius pula.

Melihat pada ketentuan umum Undangundang No. 35 Tahun 2009 tentang Narkotika menjelaskan bahwa Narkotika adalah zat atauobat yang berasal dari tanaman atau bukan tanaman, baiksintetis maupun semisintetis, yang dapat menyebabkan penurunan atau perubahan kesadaran, hilangnya rasa, mengurangi sampai menghilangkan rasa nyeri, dan dapat menimbulkan ketergantungan, yang dibedakan kedalam golongan-golongan sebagaimana terlampir dalam UU. No. 35 Tahun 2009.
Penyalahgunaan Narkotika dewasa ini semakin hari semakin meningkat pula. Dapat kita amati dari pemberitaan-pemberitaan baik di media cetak maupun elektronik yang hampir setiap hari memberitakan tentang penangkapan para pelaku penyalahgunaan narkotika oleh aparat negara baik melalui Badan Narkotika Nasional (BNN) maupun pihak Polisi Republik Indonsesia (POLRI). Meluasnya penyalagunan sekaligus korban tindak pidana narkotika ini telah merambah kesemua lapisan masyarakat tanpa terkecuali mulai dari anak-anak, remaja, pemuda, orang tua, baik yang berpendidikan maupun orang yang tidak berpendidikan serta dari berbagai jenis profesi.

Dalam Undang-undang Nomor 35 Tahun 2009 tentang Narkotika juga telah disebutkan tentang beberapa istilah yang memiliki esensi yang sama dengan pengguna Narkotika itu sendiri, antara lain Pecandu Narkotika, Penyalah Guna, Korban penyalahgunaan, Mantan Pecandu Narkotika dan Pasien. Berpijak dari berbagai istilh yang beragam terkait dengan Penyalah Guna narkotika tersebut sehingga menimbulkan dampak dan implikasi yang berbeda sehingga ada ketidak konsistenan dalam hal memperlakukan orang yang menggunakan narkotika sebagai korban penyalah guna narkotika bagi diri sendiri.

Pada prinsipnya penyalahguna narkotika mendapatkan jaminan rehabilitasi medis dan juga rehabilitasi sosial sebagaimana diatur dalam Pasal 4 butir (d), dan juga Pasal 54 yang menyebutkan bahwa "Pecandu Narkotika 
dankorban penyalahgunaanNarkotika wajib menjalani rehabilitasi medis dan rehabilitasi sosial". Namun dalam ketentuan pidana juga telah diatur sanksi pidana bagi orang yang menggunakan narkotika sebagaimana diatur dalam Pasal 127.

Namun karena Sistem Peradilan Pidana Indonesia menganut asas legalitas maka dalam praktek pada umumnya, semua kasus narkotika termasuk Pemakai narkotika untuk diri sendiri yang bukan pengedar biasanya juga selalu diproses secara hukum sesuai dengan norma hukum sebagaimana yang ditetapkan dalam UU Narkotika yaitu dengan ancaman sanksi pidana penjara. Sehingga Penyalah Guna narkotika bagi diri sendiri yang bukan pengedar dimana awalnya sebagai korban yang mestinya direhabilitasi menjadi harus menjalani pidana penjara sebagaimana diatur dalam Pasal 127. Bukan hanya sebatas itu saja Pengguna narkotika yang bukan Pengedar ketika dihadapkan didepan persidangan akan didakwa dengan pasal lain yang saling tumpang tindih. Logikanya pengguna yang mendapatkan narkotika secara melawan hukum, maka sudah barang tentu terdapat juga sekaligus beberapa perbuatan yang dilakukan pengguna tersebutsebagaimana yang dirumuskan dalam Pasal 111 dan atau Pasal 112 atau bahkan Pasal 114 yang memiliki unsur membeli, menguasai, menyimpan, atau memiliki yang akhirnya dipergunakan sendiri.

Undang-undang tentang Narkotika sendiri tidak memberikan pembedaan / garis yang jelas antara delik pidana dalam Pasal 127
UU Narkotika dengan delik pidana lain yang terdapat dalam UU Narkotika, dimana pengguna narkotika yang mendapatkan narkotika secara melawan hukum pastilah memenuhi unsur "menguasai”, "memiliki”, “menyimpan”, dan atau "membeli" narkotika dimana hal tersebut juga diatur sebagai suatu tindak pidana tersendiri dalam UU Narkotika. Dalam prakteknya aparat penegak hukum juga mengaitkan (termasuk / include / juncto) antara delik pidana pengguna narkotika dengan delik pidana penguasaan, pemilikan, penyimpanan atau pembelian narkotika secara tanpa hak dan melawan hukum dimana ancaman pidananya menjadi jauh lebih tinggi serta menggunakan sanksi minimum khusus yaitu minimal 4 tahun penjara dan denda paling sedikit Rp 800.000.000,- (delapan ratus ribu rupiah).

Banyaknya jumlah kasus penyalahgunaan narkotika khusunya penyalah guna narkotika bagi diri sendiri serta kebijakan kriminal (Criminal Policy) yang menyikapi hal tersebut secara represif sebagaimana diatur dalam Pasal 127 juntoPasal 111 dan atau Pasal 112 atau bahkan Pasal 114 UU No. 35 tahun 2009 yang lebih mengedepankan keadilan retributif tentu hal ini akan membawa konsekwensi logis bagi jumlah penghuni di Lembaga Pemasyarakatan disamping bagi pengguna yang bukan pengedar yang menjadi double victimization.

Banyaknya Nara Pidana (NAPI) narkotika yang di hukum berdasarkan hukum positif yang berlaku di indonesia menyebabkan jumlah NAPI dalam Lembaga Pemasyarakatan 
(LAPAS) menjadi mendominasi disamping belum memadainya LAPAS khusus narkotika, menyebabkan lapas yang ada di Indonesia penuh atau kelebihan kapasitas (over load). Hal ini juga senada dengan apa yang disampaikan oleh Wakil Ketua Komisi IX DPR RI, Nova Riyanti Yusuf menyebutkan bahwa $70 \%$ penghuni LAPAS saat ini dihuni oleh mereka yang tersangkut kasus narkotika. ${ }^{1}$ Dari 32 Kanwil LAPAS di Indonesia 23 lapas telah kelebihan kapasitas dan yang tidak melebihi kapasitas hanyalah berjumlah 9 (sembilan) yaitu: Yogyakarta, Jawa Tengah, Maluku, Maluku Utara, Papua, Papua Barat, Sulawesi Barat, Sulawesi Selatan, Sulawesi Tenggara. ${ }^{2}$

Tingkat hunian yang melebihi kapasitas serta lemahnya pengawasan terhadap NAPI narkotika menyebabkan banyak permasalahan. Hal ini terlihat dari seringnya terjadi pertikaian baik antara NAPI maupun antara NAPI dengan petugas penjaga LAPAS itu sendiri. Dampak dari hal itu bisa kita lihat dimana para NAPI yang banyak melarikan diri, merusak fasilitas LAPAS dan bahkan membakar LAPAS seperti yang terjadi pada hari Kamis, 11 Juli 2013, dimana LAPAS Tanjung Gusta Kelas 1 A, Sumatera Utara Medan terbakar yang mengakibatkan sekitar 300 (tiga ratus) orang NAPI berhasil meloloskan diri. ${ }^{3}$
Disisi lain dengan dikumpulkannya Pengguna, Pengedar, Bandar, Pengimport dan juga para pelaku kwalifikasi tindak pidana narkotika yang lain di dalam satu LAPAS maka yang terjadi adalah Pasar Narkotika dalam LAPAS. Keadaan ini dapat kita lihat dengan seringnya terdapat narkoba di dalam LAPAS dan bahkan ada juga narapidana yang mengendalikan peredaran narkotika dari dalam LAPAS itu sendiri, sehingga dalam praktek dilapangan LAPAS merupakan tempat transaksi narkotika yang paling aman.

Misalkan hal ini dapat kita lihat seperti yang diberitakan dalam berbagai surat kabar yang mengungkap bahwa ternyata berdasarkan razia lapas yang dilakukan oleh pihak Kepolisian dan BNN di Jawa Timur ternyata ditemukan berbagai macam jenis narkoba yang dikonsumsi dan bahkan diedarkan oleh para NAPI itu sendiri seperti Lapas narkoba Madiun, Rutan Mandaeng Sidoarjo, Lapas Lowokwaru Malang, Lapas Delta Sidoarjo, Lapas Narkoba Pamekasan, dan juga lapas pasuruan. ${ }^{4}$ Belum lagi ketika hal ini diperparah dengan keterlibatan petugas LAPAS dengan narapidana dan mendapatkan keuntungan dari transaksi narkoba menambah beban dalam pemberantasan narkoba di Indonesia

1 Suara Pembaruan, Penghuni Lapas Kasus Narkotika, http://www.suarapembaruan.com/home/70-penghunilapas-kasus-narkotika/44305, diakses 14 Desember 2014 pukul 13.10 WIB.

2 Lilik Mulyadi, Pemidanaan Terhadap Pengedar dan Pengguna Narkoba, Op.cit., Bab II.

3 Kompasiana, Di Balik Pembakaran Lapas Tanjung Gusta, http://blog.kompasiana.com/2013/07/21/dibalik-pembakaran-lapas-tanjung-gusta-575224.html, diakses 14 Desember 2014 pukul 14.10 WIB.

4 Harian Pagi SURYA, 18 Desember 2013, Spirit Baru Jawa Timur, hlm. 1. 
Berdasarkan uraian diatas, terdapat permasalahan hukum. Pertama, mengenai Sanksi tindakan sebagai sanksi alternatif dalam tindak pidana narkotika. Kedua, bentuk sanksi tindakan yang dapat dijadikan sebagai sanksi alternatif dalam reformulasi tindak pidana narkotika. Dengan demikian rumusan masalah pada tulisan ini yaitu:

1. Apakah sanksi tindakan dapat dijadikan sebagai alternatif sanksi dalam tindak pidana narkotika di Indonesia?

2. Bagaimanakah bentuk sanksi tindakan yang dapat dijadikan sebagai sanksi alternatif dalam reformulasi tindak pidana narkotika dimasa mendatang?

Tujuan dari tulisan ini ialah untuk menguji dan menganalisis apakah sanksi tindakan dapat dijadikan sebagai alternatif sanksi dalam tindak pidana narkotika di Indonesia serta untuk memahami dan menjelaskan tentang bentuk sanksi tindakan yang dapat dijadikan sebagai sanksi alternatif dalam reformulasi tindak pidana narkotika dimasa mendatang.

Tulisan ini merupakan jenis penelitian hukum normatif yang dapat diartikan sebagai prosedur penelitian ilmiah untuk menemukan kebenaran berdasarkan logika keilmuan hukum dari sisi normatifnya. ${ }^{5}$ Adapun norma yang diteliti ialah pertentangan norma sekaligus kekaburan norma dalam Pasal 4 dan Pasal 54 UU NO 35 Tahun 2009 tentang Narkotika yang intinya menjamin rehabilitasi bagi penyalah guna narkotika bagi diri sendiri akan tetapi dalam Pasal 127 diancam pidana penjara sekaligus perbuatan tersebut juga memenuhi kwalifikasi perbuatan sebagaimana yang diatur dalam Pasal 111 dan atau Pasal 112 atau bahkan Pasal 114 UU No 35 Tahun 2009.

Metode pendekatan yang digunakan yaitu Pendekatan Perundang-undangan (statute approach);Pendekatan Kasus (case approach);Pendekatan Konsep (conceptual approach); dan Pendekatan Perbandingan (comparative approach). ${ }^{6}$ Adapun teori hukum yang digunakan dalam membahas rumusan masalah pertama adalah Teori Pertanggungjawaban Pidana, teori Tujuan Pemidanaan dan teori Viktimologi serta untuk membahas rumusan masalah yang kedua adalah Teori kebijakan Hukum Pidana, Teori Keadilan Restoratif dan juga Teori Tujuan Pemidanaan.

Analisis dalam penelitian ini menggunakan deskripsi analisis dimana bahan hukum yang telah diperoleh terlebih dahulu direduksi untuk memilah kesahihannya sebagai bahan hukum serta kesesuaiannya dengan bahan penulisan jurnal ini.

\section{Pembahasan}

Dalam Undang-undang Nomor 35 Tahun 2009 tentang Narkotika adapun kwalifikasi perbuatan melawan hukum yang dikategorikan sebagai tindak pidana narkotika terdiri dari lima kategori, yaitu:

5 Johnny Ibrahim, Teori dan Metode Penelitian Hukum Normatif, Bayumedia, Malang, 2012, hlm. 57.

6 Peter Mahmud Marzuki, Penelitian Hukum, Prenada Media Group, Jakarta, 2011, hlm. 93. 
1. Kategori Pertama;

Semua perbuatan - perbuatan yang berupa memiliki, menyimpan, menguasai atau menyediakan narkotika dan prekursor narkotika.

2. Kategori Kedua;

Semua perbuatan - perbuatan berupa memproduksi, mengimpor, mengekspor atau menyalurkan narkotika dan prekursor narkotika.

3. Kategori Ketiga;

Semua perbuatan - perbuatan berupa menawarkan untuk dijual, menjual, membeli, menerima, menjadi perantara dalam jual beli, menukar atau menyerahkan narkotika dan presekutor narkotika.

4. Kategori Keempat;

Semua perbuatan - perbuatan berupa membawa, mengirim, mengangkut atau mentransit narkotika dan presekutor narkotika.

5. Kategori Kelima;

Semua perbuatan penyalahgunaan Narkotika Golongan I, II dan III bagi diri sendiri.

Terminologi Penyalahgunaan Narkotika bagi diri sendiri secara normatif memang tidak disebutkan secara tegas dalam UU No.35 Tahun 2009, namun hanya menjelaskan beberapa istilah yang memiliki esensi yang hampir sama dengan penyalahguna untuk diri sendiri, antara lain:Pecandu Narkotika, Penyalah Guna, Korban penyalahguna, Mantan Pecandu Narkotika, Pasien.
Salah satu permasalahan akibat banyaknya istilah terhadap pengguna narkotika adalah keracuaan pengaturan dimana Pasal 4 huruf d UU Narkotika yang menyatakan tujuan undang-undang Narkotika adalah "Menjamin pengaturan upaya rehabilitasi medis dan sosial bagi penyalahguna dan pecandu narkotika", akan tetapi dalam Pasal 54 UU Narkotika menyebutkan "Pecandu Narkotika dan Korban Penyalahguna Narkotika wajib menjalani rehabilitasi medis dan rehabilitasi sosial" sehingga hak penyalah guna untuk mendapat rehabilitasi sebagaimana diatur dalam Pasal 54 menjadi tidak diakui dengan adanya ancaman sanksi pidana bagi pengguna narkotika sebagaimana yang diatur dalam Pasal 127.

Penyalahguna narkotika bagi diri sendiri merupakan jenis kejahatan tanpa korban “crime without victim"dimana penyalaguna narkotika bagi diri sendiri yang tanpa disertai dengan perbuatan kwalifikasi tidak pidana lain seperti pengedar, memproduksi, Mengimpor, Mengekspor dan berbagai kwalifikasi lain dalam Undang-Undang Nomor 35 Tahun 2009, selain sebagai pelaku kejahatan namun juga sekaligus sebagai korban dari kejahatan yang dilakukannya sendiri.

Ditinjau dari segi victimologymaka penyalah guna narkotika bagi diri sendiri adalah termasuk dalam tipologi korban "self victimizing victims" yakni korban dari kejahatan yang dilakukannya sendiri. Oleh sebab itu maka, yang paling tepat dilakukan kepadanya adalah suatu sanksi tindakan dan 
bukan pidana penjara karena penyalah guna narkotika bagi diri sendiri pada hakikatnya merupakan korban dari suatu kejahatan yang perlu mendapatkan pengobatan dan/atau perawatan, dan oleh karena ia merupakan pihak yang juga mengalami kerugian dari suatu kejahatan yakni kejahatan penyalahgunaan narkotika.

Kerugian yang dialami pengguna narkotika tidak saja merasakan kerugian materi, namun juga kerugian sosial, psikis, fisik, dan kesehatan. Kerugian sosial yang dialami seorang pengguna narkotika berupa stigma atau cap buruk yang ditimpakan oleh masyarakat, seperti sebutan pengguna narkotika adalah sampah masyarakat dan sebutan buruk lainnya. Kerugian psikis yang dialami pengguna narkotika jelas kondisi kejiwaan yang tidak stabil akibat ketergantungan pada zat narkotika, apalagi jika pengguna narkotika khususnya pengguna narkotika suntik tertular virus HIV yang menyebabkan pengguna tersebut akhirnya menderita AIDS. Inilah kerugian fisik dan kesehatan sebagai akibat dari dampak penggunaan narkotika suntik yang berlipat ganda, bukan saja mendapat cap buruk akibat ketergantungan narkotika tetapi juga stigma karena terinfeksi HIV. ${ }^{7}$

Jika ditinjau dari segi kesehatan penyalahguna narkotika bagi diri sendiri terutama mereka yang sudah mengalami ketergantungan telah diteliti ahli kesehatan dan dikategorikan sebagai brain diseases atau kerusakan terhadap sel-sel otak yang bekerja di dalam tubuh manusia, dimana tubuh yang dikontrol oleh otak yang telah terganggu karena penggunaan zat-zat dalam narkotika mengakibatkan tubuh menginginkan zat tersebut untuk dikonsumsi secara terus-menerus. Akibatnya, pemidanaan tidak akan sertamerta membuat orang yang ketergantungan akan zat-zat tersebut sembuh dan tidak akan menggunakan zat tersebut lagi, namun ketergantungan ini hanya dapat ditanggulangi dengan proses medis dan sosial. $^{8}$

Ketika narkotika masuk ke dalam tubuh semua akan bekerja di otak, sehingga akan mempengaruhi perilaku maupun pola pikir orang tersebut. Perubahan tersebut melalui suatu proses yang dinamakan "Neuroadaptasi". Makin lama seseorang menggunakan narkotika akan terjadi perubahan pada ujung-ujung saraf dalam fungsinya menerima dan memberikan efek narkotika ke tubuh seseorang, sehingga pengguna tersebut harus meningkatkan dosis untuk mendapatkan efek yang sama seperti sebelumnya.

Adanya neuroadaptasi tersebut maka jumlah zat narkotika yang digunakan makin lama semakin tinggi dan apabila diturunkan atau dihentikan sama sekali akan

7 Keterangan Ahli Inang Winarso dalam putusan Mahkamah Konstitusi Republik Indonesia Nomor 48/PUUIX/2011, hlm. 67.

8 Keterangan Ahli Asmin Fransiska dalam putusan Mahkamah Konstitusi Republik Indonesia Nomor 48/PUUIX/2011, hlm. 65 . 
menimbulkan gejala putus zat, yang membuat seseorang pengguna narkotika merasa tidak nyaman baik secara fisik maupun psikologis; Narkotika bekerja di otak pada suatu area yang namaya "pusat kesenangan", karena adanya efek yang menyenangkan akibat efek positif narkotikamenyebabkan otak sulit menghapus memori yang telah terekam. Apabila seseorang pengguna melihat atau merasakan sesuatu yang tidak nyaman maka hal yang akan diingat adalah menggunakan narkotika kembali untuk mendapatkan rasa senang tersebut. Kondisi ini akan menyebabkan seseorang yang sudah ketergantungan narkotika menjadi suatu penyakit yang kronis dan kambuhan karena sulitnya melepaskan sel reseptor yang telah mengikat zat adiktif/narkotika tersebut. ${ }^{9}$

Kwalifikasi Penyalahguna narkotika bagi diri sendiri berbeda dengan jenis kwalifikasi lain yang dikategorikan sebagai tindak pidana narkotika seperti Pengedar, Pengimpor, Pengekspor, Pembawa, Penjual, yang Pemproduksi dan jenis perbuatan lain, dimana kwalifikasi perbuatan tersebut merupakan suatu kejahatan yang sangat berbahaya dan memberikan dampak kerugian yang besar baik pada korbannya maupun pada kepentingan bangsa dan negara dimasa dan generasi mendatang. Adapun yang menjadi korban penyalahguna narkotika bagi diri sendiri adalah pada umumnya para pemuda yang harusnya menjadi generasi bangsa. Sehingga selain kwalifikasi pengguna narkotika untuk diri sendiri maka setiap kwalifikasi tindak pidana narkotika harusnya memang mendapatkan sanksi pidana yang tegas dan seberat beratnya dalam rangka menyelamatkan masa depan dan generasi bangsa indonesia.

Fenomena ini memang tidak dapat dipungkiri apalagi ketika pelaku tindak pidana narkotika tersebut merupakan jaringan dari kejahatan internasional yang tidak menutup kemungkinan memiliki suatu kepentingan politik yaitu dengan memakai narkotika sebagai alat subversi (mengahancurkan lawan secara diam-diam melalui usaha-usaha agar lawan mengalami kehancuran dari dalam) dari pihak maupun negara tertentu yaitu dengan mengedarkan narkortika di indonesia dan merusak masa depan generasi muda bangsa indonesia maka suatu saat bisa menguasai dan menjajah negara kesatuan Republik Indonesia.

Sehingga sangat beralasan jika pelaku tindak pidana narkotika selain penyalahguna bagi diri sendiri memang harus di tindak tegas karena perbuatan mereka yang sangat merugikan masyarakat dan juga negara. Hal ini terlihat dari sasaran korban mereka yang pada umumnya adalah para pemuda yang harusnya penerus dan generasi bangsa. Akan tetapi jika pelaku adalah pengguna narkotika bagi diri sendiri haruslah diselamatkan karena dengan menyelamatkan korban yaitu penyalaguna narkotika bagi diri sendiri sama halnya menyelamatkan generasi dan masa depan negara ini.

Pada prinsipnya penyalahguna narkotika bagi diri sendiri adalah mendapatkan jaminan

9 Keterangan Ahli dr. Diah Setia Utami Sp.KJ, MARS, Ibid., hlm. 70. 
rehabilitasi, akan tetapi pada Pasal 127 Undang undang No 35 Tahun 2009 tentang Narkotika penyalah guna narkotika kemudiaan juga menjadi subyek yang dapat dipidana dan dapat kehilangan hak rehabilitasinya, kecuali dapat dibuktikan atau terbukti sebagai korban narkotika. Dalam praktek penerapan hukum dilapangan aplikasi dari norma pasal tersebut menjadi semakain rancu dimana sekalipun pengguna narkotika untuk diri sendiri sekaligus korban dari perbuatannya namun dia tetap dikenakan sanksi pidana sebagaimana yang dirumuskan dalam Pasal 127 yang biasanyadalam dakwaannya juga mengaitkan (termasuk / include / juncto) Pasal 111 atau Pasal 112 karena juga memenuhi unsur dalam norma pasal tersebut.

Adapun bunyi pasal pidana yang mengatur terkait dengan pengguna narkotika untuk diri sendiri adalah sebagai berikut:

Pasal 127

(1) Setiap Penyalah Guna:

a. Narkotika Golongan I bagi diri sendiri dipidana dengan pidana penjara paling lama 4 (empat) tahun;

b. Narkotika Golongan II bagi diri sendiri dipidana dengan pidana penjara paling lama 2 (dua) tahun; dan

c. Narkotika Golongan III bagi diri sendiri dipidana dengan pidana penjara paling lama 1 (satu) tahun.

Pasal 111

(1) Setiap orangyang tanpa hak atau melawan hukum menanam, memelihara, memiliki, menyimpan, menguasai, atau menyediakan Narkotika Golongan I dalam bentuk tanaman, dipidana dengan pidana penjara palingsingkat 4 (empat) tahun dan paling lama12 (dua belas) tahun dan pidana dendapaling sedikit Rp. 800.000.000,00 (delapanratus juta rupiah) dan paling banyak Rp. 8.000.000.000,00 (delapanmiliar rupiah).

\section{Pasal 112}

(1) Setiap orang yang tanpa hak atau melawan hukum memiliki,menyimpan, menguasai,ataumenyediakan Narkotika Golongan I bukan tanaman, dipidana dengan pidana penjara paling singkat 4(empat) tahun dan paling lama12 (duabelas) tahun dan pidana denda paling sedikit Rp 800.000.000,00 (delapan ratus juta rupiah) dan paling banyak $\mathrm{Rp}$ 8.000.000,00 (delapan miliar rupiah).

Jika melihat ketentuan norma tersebut maka kita dapat mengetahui bahwa pada prinsipnya penyalahguna narkotika bagi diri sendiri dikenakan sanksi pidana sebagaimana yang diatur dalam Pasal 127 dan dalam ketentuan norma Pasal 103 mengatur bahwa seorang hakim "dapat" memutuskan untuk menempatkan pengguna tersebut untuk mejalani rehabilitasi dimana masa rehabilitasi tersebut juga dihitung sebagai masa hukuman dimana sistem yang demikian dalam ilmu hukum pidana dikenal sebagai Double Track System.

Selain dengan ancaman sanksi pidana sebagaimana yang diatur dalam Pasal 127 tersebut, seorang penyalahguna narkotika 
bagi diri sendiri juga dituntut dengan rumusan Pasal 111 dan atau Pasal 112 karena ketika seseorang memenuhi unsur Pasal 127 sudah barang tentu sekaligus memenuhi unsur dalam Pasal 111 dan atau Pasal 112 yaitu unsur yang bersifat alternatif yaitu "memiliki, menyimpan, menguasai" dimana unsur ini tidak harus terpenuhi keseluruhan namun salah satupun dari unsur tersebut terpenuhi sudah termasuk dalam kategori norma tersebut karena unsur dalam pasal ini adalah bersifat alternatif.

Jika ditelusuri lebih jauh sebelum seseorang menyalahgunakan narkotika bagi diri sendiri dan juga yang memenuhi unsur "memiliki, menyimpan, menguasai" juga ada suatu perbuatan asal yang dilakukannya untuk dapat menyalahgunakan narkotika tersebut yaitu berupa tindakan "membeli" yang memenuhi kwalifikasi tindak pidana narkotika misalnya Pasal 114(1) dengan ancaman pidana seumur hidup atau pidana penjara paling singkat 5 (lima) tahun dan paling lama 20 (dua puluh) tahun dan juga disertai dengan pidana denda palingsedikit Rp1.000.000.000,00 (satu miliar rupiah)dan paling banyak Rp10.000.000.000,00(sepuluhmiliarrupiah).

Jadi ketika seseorang menyalah gunakan narkotika bagi sendiri serta tidak diberikan batasan yang jelas dengan pasal lain maka perbuatan tersebut juga bisa memenuhi pasal tindak pidana narkotika yang lain sepanjang memenuhi unsur "memiliki”, "menyimpan", "menguasai" dan atau "membeli" narkotika dengan cara tanpa hak atau melawan hukum dimana ancaman pidananya jauh lebih berat yaitu pidana penjara dan denda dengan kumulasi "minimum khusus" sehingga tidak ada pilihan lain bagi hakim untuk memutus rehabilitasi tanpa pidana penjara dan denda yang tinggi karena adanya batas pemidanaan yang tinggi pula dalam pasal tersebut. Hal ini sesuai dengan teori Pertanggungjawaban pidana khususnya aliran dualistis ${ }^{10}$ yang pada intinya menyatakan bahwa semua perbuatan pidana harus pidana sepanjang memenuhi unsur-unsur dari norma pasal pidana tersebut.

Logikanya, secara sederhana dapat kita ketahui bahwa ketika seseorang menyalahgunakan narkotika bagi diri sendiri sudah barang tentu sebelumnya telah terjadi suatu perbuatan yang terkait dengan sumber barang yang diperolehnya tersebut. Secara umum hal ini biasanya terjadi diawali ketika adanya pengaruh konflik internal maupun keadaan eksternal pelaku sehingga dia menerima tawaran barang haram tersebut dalam rangka penenangan diri untuk sesaat atau bahkan hanya untuk coba-coba, sehingga pada suatu waktu tertentu ketika pengguna sudah berada pada posisi yang kecanduan akibat dari zat tersebut maka sipengguna biasanya juga akan mencari sendiri atau membeli zat nakotika tersebut untuk dapat dikonsumsi.

Berdasarkan pada uraian peristiwa pada umumnya, biasanya sebelum adanya perbuatan penyalahgunaan narkotika bagi diri sendiri sesungguhnya sudah terjadi suatu perbuatan 
yang mengawalinya yaitu yang memenuhi unsur "memiliki, menyimpan, menguasai, dan atau membeli" sebagaimana yang dimaksud dalam Pasal 111 dan atau Pasal 112 maupun Pasal 114 UU NO. 35 tahun 2009.

Keadaan yang demikian dapat kita jumpai pada kasus penyalagunaan narkotika bagi diri sendiri pada umumnya. Dimana secara umum yang awalnya seseorang melakukan penyalahgunaan narkotika bagi diri sendiri karena norma pasal yang saling menganulir/ bertentangan (conflik of norm) dan bahkan adanya norma pasal tertentu yang kabur (obscur) sehingga penyalahguna narkotika bagi diri sendiri tersebut selalu berakhir dengan pidana penjara dan juga disertai degan kwalifikasi tindak pidana yang lain.

Hal ini misalanya dapat kita lihat pada

\section{Putusan Nomor: 130/Pid.Sus/2011/PN.}

Malang yang menjatuhkan sanksi pidana bagi seorang mahasiswa yang berinisial SRR yang menyalagunakan narkotika bagi diri sendiri karena terpengaruh oleh temannya tanpa disertai dengan kwalifikasi lain seperti mengedarkan / menjual dst, namun dalam dakwaan Jaksa Penuntut Umum juga mendakwa dengan pasal tindak pidana narkotika kwalifikasi lain yang menurut penilaian hakim dianggap juga memenuhi unsur Pasal 111 UU No. 35 tahun 2009 sehingga dihukum dengan pidana penjara 4 (empat) tahun serta denda Rp. 800.000.000,(delapanratus juta rupiah) serta menetapkan apabila denda tersebut tidak dibayar, maka diganti dengan hukum penjara selama 3 (tiga) bulan.
Bagi Penyalahguna narkotika tersebut sesungguhnya adalah korban terhadap tubuh/kesehatan sendiriatas perbuatan yang dilakukannya dan sekaligus penderitaan berupa perampasan hak dalam hal menjalani pidana penjara. Hal ini juga semakin diperparah dengan kondisi LAPAS saat ini yang belum menjalankan fungsinya dengan maksimal seperti masih adanya penggabungan pengguna narkotika dengan pelaku tindak pidana lain, terdapatnya orang yang menggunakan narkotika bahkan sebagai pengendali pengedaran narkotika di dalam LAPAS sehingga sangat dimungkinkan ketika seorang narapidana pengguna narkotika yang sudah selesai menjalani masa tahanannya juga melakukan perbuatan yang sama (residivis) dan bahkan dengan cara yang jauh lebih lihai sebagai akibat dari penggabungan semua pelaku kejahatan dalam LAPAS.

Penyalahguna narkotika bagi diri-sendiri semestinya harus di posisikan sebagai orang yang sakit yang butuh pengobatan dan pemulihan akibat dari dampak negatif dari penyalahgunaan zat narkotika yang digunakannya (korban yang harusnya hak haknya dilindungi sebagai korban). ${ }^{11}$ Sehingga sanksi yang harusnya harus diterapkan khusus kepada penyalahguna narkotika bagi diri sendiri yang tanpa disertai dengan kwalifikasi tindak pidana utama yang lain adalah suatu jenis sanksi yang dapat memulihkan keadaanya terhadap keadaaan semula yaitu berupa suatu sanksi tindakan. 
Berdasarkan tujuan pemidanaan khususnya yang bersifat relatif (deterrence) memandang bahwa pidana tersebut ditujukan kepada hari hari yang akan datang, yaitu dengan maksud mendidik orang yang telah berbuat jahat menjadi baik kembali ${ }^{12}$ serta orang yang sakit dalam hal ini orang yang memiliki ketergantungan dengan narkotika jadi sembuh atau bebas dari ketergantungan (kecanduan). Di sisi lain jika penyalahguna narkotika bagi diri sendiri menggunakan zat narkotika tersebut, dimana dia adalah orang yang sakit (ketergantungan pada obat) maka tidak tepat mempertanggungjawabkannya dengan pidana penjara melainkan harus berupa suatu tindakan yang dapat menyembuhkannya sehingga bebas dari ketergantungan pada zat tersebut dan dapat pulih kedalam keadaan semula.

Berdasarkan uraian dan berbagai argumen yang dikemukan diatas maka sanksi tindakan merupakan suatu sanksi yang hendaknya di pertimbangkan juga harus memberikan suatu kemanfaatan terhadap pengguna narkotika bagi diri sendiri yang tanpa disertai kwalifikasi tindak pidana narkotika yang lain.

Bentuk Sanksi Tindakan sebagai Sanksi Alternatif dalam Reformulasi Tindak Pidana Narkotika di Masa Mendatang

Undang-Undang Nomor 35 Tahun 2009 tentang Narkotika sudah mengklasifikasikan suatu perbuatan yang dikategorikan sebagai tindak pidana narkotika beserta dengan sanksi pidana sesuai dengan jenis kwalifikasi perbuatan yang dilakukannya. Kwalifikasi perbuatan penyalahguna narkotika bagi diri sendiri sebagaimana diatur dalam Pasal 127 pada prinsipnya menganut sistem pemidanaan ganda (double track system), dimana hakim yang memeriksa perkara penyalaggunaan narkotika tersebut diberi kebebasan untuk memutus untuk menempatkan penyalahguna narkotika bagi diri sendiri dipenjara atau memerintahkan untuk direhabilitasi.

Disamping itu berdasarkan pada Pasal 103 UU No 35 tahun 2009 tentang Narkotika Mahkamah Agung RI telah membuat suatu terobosan dengan mengeluarkan Surat Edaran Mahkamah Agung No 04 Tahun 2010 tentang penetapan penyalahgunaan, korban penyalahgunaan, dan Pecandu Narkotika ke dalam Lembaga Rehabilitasi Medis dan Rehabilitasi Sosial sebagai pengganti dari Surat Edaran Mahkamah Agung Nomor 07 Tahun 2009. Akan tetapi dalam Penerapannya SEMA tersebut terkendala karena untuk memutuskan perkara pengguna narkotika hakim tidak dapat mengintervensi aparat penegak hukum lainya (penyidik dan penuntut umum).

Selain SEMA No 04 Tahun 2010 belakangan ini juga ada beberapa ketentuan lain seperti Peraturan Bersama ketua Mahkamah Agung, Menteri Hukum Dan Hak Asasi Manusia, Menteri Kesehatan, Menteri Sosial, Jaksa Agung, Kepala Kepolisian Negara Republik Indonesia, Kepala Badan Narkotika Nasional Republik Indonesia, 
tentang Penanganan Pecandu Narkotika dan Korban Penyalahgunaan Narkotika ke dalam Lembaga Rehabilitasi yang ditetapkan di Jakarta pada tanggal 11 maret 2014. Selain itu Badan Narkotika Nasional Republik Indonesia telah mengeluarkan MAKLUMAT Nomor: MAK/01/III/2014/BNN Tentang Penyelamatan Pengguna Narkoba yang dibuat di Jakarta pada tanggal: 27 Maret 2014 yang itinya menyatakan bahwa pemulihan berupa Rehabilitasi merupakan cara terbaik yang di terapkan kepada penyalaguna narkotika bagi diri sendiri (korban penyalah guna).

Akan tetapi sangat disayangkan karena dalam praktek dilapangan banyak penegak hukum baik dari penyidik, penuntut, hingga hakim masih terbelengguh dengan konsep legalistik, yang menuntut dan memutus perbuatan tersebut sebagai perbuatan pidana dan harus menjalani pidana penjara karena perbuatan yang demikian juga memenuhi unsur Pasal 111 dan atau Pasal 112, Pasal 114 serta pasal lain sepanjang memenuhi unsur “memiliki”, "menyimpan”, "menguasai” dan atau "membeli" sehingga korban penyalah guna tersebut menjadi bermuara di penjara dan tidak mendapatkan rehabilitasi.

Penegakan hukum yang demikian terjadi karena sesungguhnya telah terjadi suatu kekaburan norma (obscur norm) sekaligus juga pertentangan antara norma yang satu dengan norma yang lain (konflik of norm). Kekaburan norma yang dimaksud adalah ketidak jelasan arti dan batasan dari pada definisi penyalahguna narkotika untuk diri sendiri dimana tiap definisi tersebut memiliki makna dan konsekwensi yang berbeda beda juga. Disisi lain Pasal 111 dan atau Pasal 112, Pasal 114 dan juga pasal kwalifikasi tindak pidana narkotika yang lain sepanjang kata "memiliki”, "menyimpan”, "menguasai” dan atau "membeli" tidak menyebutkan secara jelas dan tegas tentang sasaran pasal tersebut sehingga norma pasal tersebut dapat dimaknai dan ditujukan pada penyalahguna narkotika bagi diri sendiri (pecandu), pengedar, penjual, Pemroduksi, Pengimport dan atau juga kwalifikasi tindak pidana narkotika yang lain. Pada hal tiap kwalifikasi perbuatan tersebut memiliki makna, konsekwensi dan dampak kerugian yang berbeda-beda juga.

Dalam rangka Penyelamatan penyalahguna narkotika bagi diri sendiri dari ancaman pidana penjara, maka hal yang perlu dilakukan adalah melakukan reformulasi norma Undangundang Nomor 35 tahun 2009 khusnya terkait kedudukan penyalah guna narkotika melalui pengaturan jenis sanksi yang tepat dan memberikan kemanfaatan sesuai dengan kedudukannya serta penegasan tujuan pasal kwalifikasi tindak pidana narkotika yang lain yang unsurnya dapat terpenuhi secara otomatis ketika seseorang menyalah gunakan narkotika bagi diri sendiri.

Permasalahan sentral dalam kebijakan penal adalah penentuan perbuatan apa yang seharusnya dijadikan tindak pidana (yaitu melalui kebijakan kriminalisasi), dan sanksi apa yang sebaiknya dijatuhkan kepada sipelanggar (yaitu melalui kebijakan 
penalisasi).${ }^{13}$ Barda Nawawi Arief dan Muladi menyatakan bahwa hubungan antara penetapan sanksi pidana dan tujuan pemidanaan adalah titik penting dalam menentukan strategi perencanaan politik kriminal. Menentukan tujuan pemidanaan dapat menjadi landasan untuk menentukan cara, sarana atau tindakan yang akan digunakan. ${ }^{14}$ Selanjutnya Barda Nawawi Arief menegaskan bahwa politik kriminal merupakan bagian integral dari upaya perlindungan masyarakat (social defence) dan upaya untuk mencapai kesejahteraan masyarakat (social welfare). Olehkarena itu, tujuan akhir atau tujuan utama dari politik kriminal adalah "perlindungan masyarakat untuk mencapai kesejahteraan masyarakat". ${ }^{15}$

Dalam rangka reformulasi kebijakan sanksi khususnya bagi pengguna narkotika kedepan yaitu dengan menerapkan sansi tindakan perlu mempertimbangkan jenis atau bentuk dari sanksi tindakan yang tepat dan bermanfaat dalam rangka menyelamatkan penyalaguna narkotika bagi diri sendiri (pecandu). Untuk menentukan jenis sanksi tindakan tersebut perlu memperhatikan beberapa hal seperti konvensi negara-negara di dunia mencerminkan paradigma baru untuk menghindari peradilan pidana. Restorative justice (selanjutnya diterjemahkan menjadi keadilan restoratif)adalah alternatif yang populer diberbagai belahan dunia untuk penanganan pelaku tindak pidana yang bermasalah dengan hukum karena menawarkan solusi yang komprehensif dan efektif. ${ }^{16}$

Untuk memahami secara utuh tentang jenis sanksi tindakan yang relefan dan ideal yang mestinya diterapkan terhadap penyalahguna narkotika bagi diri sendiri dapat kita liahat dari tujuan pembuatan yang sekaligus sebagai roh dalam UU No 35 tahun 2009 sebagaimana yang diatur dalam Pasal 4 (d) "menjamin pengaturan upaya rehabilitasi medis dan sosial bagi Penyalah Guna dan pecandu Narkotika”. Hal ini kemudian ditegaskan kembali dalam Pasal 54 yang berbunyi "Pecandu Narkotika dan korban penyalahgunaan Narkotika wajib menjalani rehabilitasi medis dan rehabilitasi sosial". Hal ini menunjukkan bahwa sanksi yang harusnya diterapkan bagi penyalahguna narkotika bagi diri sendiri adalah berupa sanksi tindakan yang wujudnya berupa "rehabilitasi medisdanrehabilitasisosial" dan bukan sanksi pidana sebagaimana yang diatur dalam Pasal 127.

Rehabilitasi Medis yang dimaksud adalah suatu proses kegiatan pengobatan secara terpadu untuk membebaskan pecandu dari ketergantungan narkotika. Sedangkan Rehabilitasi Sosial yang dimaksud adalah suatu proses kegiatan pemulihan secara terpadu, baik fisik, mental maupun sosial,

13 Muladi dan Barda Nawawi Arief, Teori-teori dan Kebijakan Pidana, Op.cit., hlm. 160.

14 Ibid., hlm. 95.

15 Barda Nawawi Arief, Bunga Rampai Kebijakan Hukum Pidana, Perkembangan Penyusunan Konsep KUHP Baru, Op.cit, , hlm. 4.

16 Gordon Bazemore dan Mara Schiff, dalam DS. Dewi dan Fatahillah A. Syukur, Mediasi Penal: Penerapan Restorative Justice di Pengadilan Anak Indonesia, Op.cit., hlm. 4. 
agar bekas pecandu Narkotika dapat kembali bersosialisasi dalam kehidupan masyarakat. ${ }^{17}$ Jadi pedoman kriteria yang mestinya digunakan untuk menerapkan rehabilitasi bagi pelaku tindak pidana narkotika adalah dilihat dari sikap batin (mens rea / criminal intention) dari sipelaku tindak pidana tersebut. Jika pelaku tindak pidana narkotika melakukan suatu perbuatan dan terbukti bahwa sikap batinnya sesuai dengan perbuatan yang dilakukannya maka tepat jika diterapkan hukuman pidana yang paling berat bagi pelaku tindak pidana narkotika tersebut dalam rangka memberantas peredaran gelap narkotika yang merupakan kejahatan yang bersifat transnasioal. Misalnya apabila tuan $\mathrm{X}$ menjual, mengedarkan, mengimport dan atau memperoduksi zat berupa narkotika dimana dia bermaksud untuk mendapatkan keuntungan dari perbuatan yang dilakukannya atau bahkan hal tersebut merupakan pekerjaan bahkan mata pencaharian baginya maka tepat dan beralasan jika kepada tuan $\mathrm{X}$ tersebut dikenakan sanksi pidana yang berat baik berupa Penjara, denda dan atau bahkan pidana mati.

Namun sekalipun perbuatan penyalahguna narkotika bagi diri sendiri memenuhi unsur kwalifikasi tindak tindak pidana yang diatur dalam pasal yang lain, sepanjang niat (mens rea / criminal intention) sipelaku adalah untuk digunakan sendiri akibat dari suatu ketergantungan pada jenis narkotika tersebut maka sipelaku tidak boleh diterapkan sanksi pidana penjara melainkan harus secara tegas mengatur sanksi tindakan yang wujudnya berupa rehabilitasi medisdanrehabilitasisosial. Atau dalamartisederhana, setiap penyalahguna narkotika bagi diri sendiri tanpa disertai dengan jenis kewalifikasi tindak pidana lain seperti mengedar, menjual, import, produksi tidak dikenakan sanksi pidana penjara melainkan wajib untuk di rehabilitasi

Misalnya apabila si A yang sedang ketergantungan pada zat narkotika, dimana dalam rangka menenangkan dirinya atas suatu derita ketergantungan yang dideritanya dia membeli narkotika tersebut sehingga dia sebagai pemilik juga menguasai dan bahkan meyimpan dengan maksud untuk stok pemakaian berikutnya bagi diri sendiri, maka dalam hal ini si A harus di rehabilitasi dan bukan dipenjara sekalipun unsurnya telah memenuhi kwalifikasi tindak pidana lain sebagaimana yang diatur dalam pasal 111, pasal 112, pasal 114 dan pasal lain yang unsurnya terpenuhi atas perbuatan tersebut. Karena tujuan utamanya dalam hal memiliki, menyimpan, menguasai atau bahkan membeli adalah untuk pemakaian bagi diri sendiri yang kebetulan memenuhi unsur kwalifikasi tindak pidana narkotika yang lain.

Atau dalam rangka reformulasi undang undang narkotika kedepan harus membuat suatu penegasan bahwa Pasal 111, 112,114 dan pasal lain yang memenuhi unsur "memiliki”, “menyimpan”, "menguasai” dan atau "membeli" adalah pasal yang 
ditujukan terhadap pengedar, pengimport, orang yang memproduksi dan kwalifikasi tindak pidana narkotika yang lain dan bukan ditujukan pada penyalahguna narkotika bagi diri sendiri. Apabila penyalahguna narkotika bagi diri sendiri memenuhi unsur tersebut dan terbukti bahwa sikap batin (mens rea / criminal intention) dari sipelaku tidak lebih dari pada untuk digunakan bagi diri sendiri maka dalam rangka penyelamatan korban penyalaguna narkotika bagi diri sendiri hakim diwajibkan untuk memutuskan untuk menerapkan sanksi tindakan berupa rehabilitasi medisdanrehabilitasisosial bagi si pelaku.

Dengan menghapuskan ketentuan pidana dan mewajibkan untuk merehabilitasi penyalah guna narkotika bagi diri sendiri paling tidak hal itu dapat menyelamatkan masa kini maupun masa depan dari penyalahguna tersebut, serta disisi lain dapat mengurangi beban konflik dan kerugian yang dialami negara. Karena dengan kebijakan pidana selama ini yang selalu memutuskan untuk pidana penjara bagi penyalahguna narkotika untuk diri sendiri tersebut sesungguhnya menambahkan beban penderitaan baginya karena Pengguna tersebut sesungguhnya sudah kehilangan masa lalu akibat pemakaian narkotika yang dia gunakan, masa kini dan juga kehilangan masa depannya sendiri dan juga masa depan generasi bangsa negara
Indonesia akibat dampak negatif dari suatu pidana penjara yang diterapkan padanya.

Sanksi tindakan berupa rehabilitasi untuk penyalah guna narkotika bagi diri sendiri sesuai dengan tujuan pemidanaan yaitu teori treatmentyang berpendapat bahwa pemidanaan sangat pantas diarahkan kepada pelaku kejahatan, bukan pada perbuatannya. Pemidanaan yang dimaksud oleh aliran ini adalah untuk memberikan tindakan perawatan (treatment) dan perbaikan (rehabilitation) kepada pelaku kejahatan sebagai pengganti dari penghukuman. Aliran ini didasarkan pada alasan bahwa pelaku kejahatan adalah orang yang sakit sehingga membutuhkan tindakan perawatan (treatment) dan perbaikan (rehabilitation). ${ }^{18}$

Sehingga dalam hal ini pelaku penyala guna narkotika bagi diri sendiri adalah sebagai orang yang sakit yang memerlukan pengobatan berupa suatu tindakan perawatan (treatment) dan perbaikan (rehabilitation) berupa rehabilitasi medis dan juga rehabilitasi sosial tanpa disertai dengan pidana penjara. Sehingga rehabilitasi bagi penyalahguna narkotika bagi diri sendiri merupakan sanksi alternatif yang efektif yang sesuai dengan kondisi penjahat bukan dengan sifat kejahatan dalam rangka memulihkannya kedalam keadaan semula sehingga dapat berintegrasi kembali dengan masyarakat. 
Hal ini sesuai dengan yang disampaikan dr. Kusman Suriakusumah, Sp.Kj.MPH, ${ }^{19}$ pengguna narkoba bisa pulih total harus memenuhi empat hal yaitu Drugs free (bebas narkoba), Crime free (bebas dari criminal) Produktif (bekerja) dan Health life (hidup sehat), Bagi mantan penyalah guna narkoba dapat dikatakan produktif, jika mantan penyalah guna narkoba tersebut sudah mampu bekerja sendiri. Oleh karena itu dibutuhkan kegiatan-kegiatan bagi mereka yang dapat membuka jejaring untuk memperoleh pekerjaan sehingga penyalah guna narkotika tersebut pulih total dan menjauhkan diri dari obat terlarang tersebut.

Menerapkan rehabilitasi terhadap penyalahguna narkotika bagi diri sendiri merupakan jenis sanksi tindakan yang dapat memulihkan kedalam keadaaan semula atau jenis sanksi yang mencerminkan nilai Restorative justice. Penerapan rehabilitasi ini dapat menggunakan fasilitas kesehatan berupa rumah sakit dan juga puskesmas yang ada di indonesia.

Dimana potensi pelayanan rehabilitasi di Indonesia sangat besar yaitu dengan 2.200 Rumah Sakit dan 11.000 Puskesmas yang tersebar di seluruh Indonesia. ${ }^{20}$ Rehabilitasi besar-besaran dalam rangka penyelamatan pengguna narkotika bagi diri sendiri dapat kita bandingkan dengan negara Thailand yang sudah berhasil merehabilitasi empat ratus ribu orang pertahun dengan menggunakan rumah sakit dan puskesmas serta Lembaga tangsitangsi kesehatan TNI POLRI. ${ }^{21}$

Sebagai perbandingan formulasi pengaturan penyalah guna narkotika dapat kita lihat di negara Portugal. Pengaturan di Portugal (Portugal's Law 30/2000) menyatakan bahwa pecandu narkotika yang memiliki narkotika untuk digunakan sendiri tetap terlarang, namun pelanggaran dari aturan ini akan dianggap pelanggaran administratif dan bukan lagi dianggap sebagai kejahatan. Kebijakan dekriminalisasi di Portugal bukan berarti bahwa menempatkan penyalahgunaan narkotika sebagai suatu hal yang legal, namun memisahkan dengan tegas antara penyalahguna narkotika dengan pengedar atau penjual, untuk kemudian diperlakukan berbeda pula. ${ }^{22}$

Kesimpulan dari kajian terhadap kebijakan yang demikian yaitu dengan menghilangkan rasa takut terhadap pemidanaan terhadap penyalah guna narkotika, Portugal telah berhasil mendorong, memotivasi, dan memberi kesempatan penyalahguna untuk menyembuhkan diri kemudian menjadi contoh bagi lingkungan sekitar. Berkaca dari keberhasilan di Portugal tersebut berbagai negara mulai juga mempertimbangkan dekriminalisasi terhadap penyalah guna narkotika. $^{23}$

19 Majalah SINAR edisi II - 2014 Badan Narkotika Nasional Republik indonesia, Sinergitas BNN dan POLRI dalam P4GN, hlm. 43.

20 Ibid., hlm. 7.

21 Nanang Iskandar (Kepala BNN), Roger, Layak Ditahan atau Direhab, ILC di TV One, 25 Februari 2014. 
Pengalaman terbaik (best practices) dalam penanggulangan penggunaan Narkotika di manca negarakhususnya di Australia, juga menunjukkan bahwa diversi ke treatment dan rehabilitasi bagi pengguna Napza terbukti lebih efektif dan murah dibanding pemenjaraan. Drug and Alcohol Review (2001) 20,281-294 Diversion strategies for Australian drug-related offenders. Semangat ini cocok dengan filosofi reintegrasi dari program pemasyarakatan itu sendiri yang telah ada di dalam Undang-Undang Nomor 35 Tahun 2009 yang tercantum dalam Pasal 127 ayat (3) dan Pasal 128 ayat (3). Pasalpasal inilah yang seharusnya menjadi prioritas dalam penegakan hukum bagi pengguna dan pecandu. ${ }^{24}$

Sebagaimana keberhasilan yang diraih oleh negara tersebut maka harusnya Indonesia dapat berkaca bahwa penegak hukum dalam hal ini Polisi, Jaksa Penuntut Umum, BNN maupun Hakim menempatkan penyalah guna narkotika sebagai orang yang sakit sekaligus sebagai korban dari suatu tindak pidana yang harus di rehabilitasi sehingga fokus penegak hukum ke depan adalah menangkap pengedar yang merupakan pelaku kejahatan narkotika yang sebenarnya.

\section{Simpulan}

Berdasarkan hasil analisis sebagaimana yang diuraikan diatas, maka dapat ditarik kesimpulan sebagai berikut:
1. Sanksi tindakan dapat dijadikan sebagai alternatif sanksi dalam tindak pidana narkotika di Indonesia yaitu khusus untuk penyalaguna narkotika bagi diri sendiri yang tanpa disertai dengan kwalifikasi tindak pidana narkotika yang lain seperti Pengedar, Pengimport, Penyedia maupun yang memproduksi. Hal ini didasarkan pada keadaan dan kedudukan Penyalah Guna yang merupakan sebagai orang yang sakit sekaligus korban dari perbuatan yang dilakukannya, yang harusnya mendapatkan suatu perlakuan khusus untuk dapat pulih kedalam keadaan semula / tidak untuk dipenjara. Hukum positif tindak pidana narkotika saat ini menganut Double Track System. Akan tetapi dalam prakteknya para penegak hukum baik Penyidik dan Penuntut Umum mendakwa Penyalah Guna tersebut dengan Pasal 111, Pasal 112 atau bahkan Pasal 114 dengan ancaman pidana khusus yaitu minimal 4 tahun penjara.

2. Bentuk sanksi tindakan yang dapat dijadikan sebagai sanksi alternatif dalam reformulasi tindak pidana narkotika dimasa mendatang adalah sesuatu yang sesuai dengan kondisi penyalahguna narkotika sebagai orang yang sakit dan sesuai dengan tujuan pembentukan UU No 35 Tahun 2009 tentang Narkotika yang sekaligus roh dari pembuatan undangundang tersebut adalah berupa suatu

24 Irwanto (Guru Besar Fakultas Psikologi Unika Atma Jaya, Jakarta), Op.cit., hlm. 74. 
"rehabilitasi medisdan rehabilitasisosial", sebagai tindak lanjutnya Mahkamah Agung juga sudah mengeluarkan SEMA nomor 4 Tahun 2010 akan tetapi masih sulit dalam implementasinya.

Berdasarkan pada hasil penelitian ini, penulis memberikan rekomendasi:

1. Sebelum adanya reformulasi UU No 35 tahun 2009, harusnya para penegak hukum mulai dari penyidik, BNN, Penuntut Umum maupun hakim harus memahami dan dapat mengambil kebijakan bahwa penyalaguna narkotika adalah korban dan orang sakit yang butuh pengobatan sehingga tidak layak untuk diterapkan pidana penjara.

2. Pemberantasan tindak pidana narkotika terutama pengedar narkotika merupakan komitmen kita bersama terutama para penegak hukum. Pemberantasan peredaran narkotika memang hal yang amat sangat sulit namun jangan karena kesulitan menangkap pengedar sehingga penyalah guna narkotika bagi diri sendiripun menjadi korban dalam pemberantasan peredaran gelap narkotika. Jadi dalam penegakan hukum kedepan harusnya penegak hukum lebih fokus pada para pengedar maupun bandar narkotika.

3. Dalam rangka reformulasi Undang Undang Nomor 35 tahun 2009 tentang Narkotika dimasa mendatang hendaknya lembaga legislatif maupun eksekutif merumuskan dengan tegas bahwa sanksi yang harus diterapkan untuk penyalaguna narkotika bagi diri sendiri adalah sanksi tindakan berupa "rehabilitasi medisdanrehabilitasisosial" serta menegaskan bahwa Pasal 111, Pasal 112 dan Pasal 114 adalah dikhususkan bagi pengedar dan bukan untuk Penyalah Guna (Pecandu).

4. Dalam rangka memulihkan dan menjamin hak korban kejahatan narkotika maka perlu diadakan amandemen terhadap Undang-Undang Nomor 35 Tahun 2009 Tentang Narkotika dengan merubah ketentuan Pasal 127 dengan usulan ketentuan yang baru sebagai berikut:

\section{Pasal 127}

(1) Setiap Penyalah Guna Narkotika Golongan I, Golongan II dan Golongan III bagi diri sendiri wajib menjalani rehabilitasi medis dan rehabilitasi sosial dalam rangka pemulihan terhadap Penyala Guna bagi diri sendiri kedalam keadaan semula.

(2) Dalam hal penyalagunaan narkotika bagi diri sendiri memenuhi unsur kwalifikasi tindak pidana narkotika yang diatur dalam pasal yang lain maka harus di nilai dari "sikap batin / mens rea" dari sipelaku, sepanjang sikap batinnya untuk digunakan sendiri untuk kebutuhan ketergantungannya maka hakim wajib memutuskan untuk diterapkan sanksi tindakan berupa rehabilitasi medis dan rehabilitasi sosial.

(3) Penyalah guna narkotika bagi diri sendiri adalah korban dari Tindak Pidana Narkotika. 


\section{DAFTAR PUSTAKA}

\section{Buku}

Abdurrahman, 2007, Ilmu Hukum, Teori Hukum dan Ilmu Perundangundangan, Citra Aditya Bakti, Bandung.

Ahmad syaufi, 2014, Mediasi Penal sebagai Alternatif Penyelesaian Perkara Pidana Beraspek Perikatan, Disertasi, FH Universitas Brawijaya.

Andi Hamzah, 2010, Asas-asas Hukum Pidana, edisi revisi, Rineka Cipta, Jakarta.

Allison Morris and C. Brielle Maxwell, 2001, Restorative Justice for Juveniles; Konferencing Mediation and Circles, Hart Publishing, Oxford-Portland Oregon.

Arif Gosita, 1989, Masalah Perlindungan

Anak, Akademika Pressindo, Jakarta.

Bambang Poernomo, 1988, Kapita Selekta Hukum Pidana, Liberty, Yogyakarta.

Barda Nawawi Arief, 2002, Bunga Rampai

Kebijakan Hukum Pidana, Citra Aditya Bakti, Bandung. , 2007, Masalah Penegakan Hukum dan Kebijakan Hukum Pidana dalam Penanggulangan Kejahatan, Kencana Prenada Media, Jakarta. , 2011, Bunga Rampai Kebijakan Hukum Pidana, Perkembangan Penyusunan Konsep KUHP Baru, Kencana Pradana Media Group, Jakarta. , 2009, Kebijakan Legislatif dalam Penanggulangan Kejahatan dengan Pidana Penjara, Genta Publishing, Semarang.

1994, Beberapa Aspek Pengembangan Ilmu Hukum Pidana: Menyongsong Generasi Baru Hukum Pidana Indonesia, Naskah Pidato Pengukuhan Guru Besar dalam Ilmu hukum pada Fakultas Hukum Universitas Diponegoro, Semarang. , 2011, Bunga Rampai Kebijakan Hukum Pidana, Perkembangan Penyusunan Konsep KUHP Baru, Kencana Pradana Media Group, Jakarta.

Roeslan Saleh, 1983, Perbuatan Pidana dan Pertanggungjawaban Pidana, Aksara Baru, Jakarta.

--------, 1982, Pikiran-pikiran tentang Pertanggungjawaban Pidana,

Cetakan I, Ghalia Indonesia, Jakarta.

Rudolp J. Gerber and Patrick D. Mcanany, 1970, Philosophy of Punishment, dalam The Sociology of Punishment \& Correction.

Satjipto Rahardjo, 1986, Ilmu Hukum, Alumni, Bandung.

Samidjo, 1985, Pengantar Hukum Indonesia, Armico, Bandung.

Septa Candra dkk, 2012, Hukum Pidana dalam Perspektif, Editor Agustinus Pohan dkk, Pustaka Larasan, Bali. 
Siswanto, 2012, Politik Hukum dalam

Undang-undang Narkotika, Rineka

Cipta, Jakarta.

Soetandyo Wignjosoebroto, 2002, Hukum:

Paradigma, Metode dan Dinamika

Masalahnya, ELSAM HUMA, Jakarta.

Soerjono Soekanto, 1986, Pengantar

Penelitian Hukum, UI Press, Jakarta. , Sri Masmudji, 2004, Penelitian

Hukum Normatif suatu Tinjauan

Singkat, RajaGrafindo Persada,

Jakarta.

Sofyan Sastrawidjadja, 1995, Hukum Pidana

(Asas Hukum Pidana sampai dengan

Alasan Peniadaan Pidana), Armico, Bandung.

Sudarto, Hukum Pidana I, 1990, Semarang, Yayasan Sudarto-Fakultas Hukum

UNDIP. , 1981, Hukum dan Hukum Pidana,

Alumni, Bandung. , 1981, Kapita Selekta Hukum

Pidana, Bandung, Alumni.

Sunaryati Hartono, 1994, Penelitian Hukum

di Indonesia Pada Akhir Abad ke-20,

Alumni, Bandung.

Hari Sasangka, 2003, Narkotika dan

Psikotropika dalam Hukum Pidana,

Penerbit Mandar Maju, Bandung.

Anton M. Moelyono, 1988, Kamus Besar

Bahasa Indonesia, Balai Pustaka, Jakarta.

Juliana Lisa \& Nengah Sutrisna W, 2013, Narkoba, Psikotropika dan
Gangguan Jiwa, Tinjauan Kesehatan dan Hukum, Nuha Medika, Yogyakarta.

Soedjono D, 1997, Patologi Sosial, Cetakan ke-II, Alumni, Bandung.

Smith Kline dan Frech Clinical, 2007, A Manual for Law Enforcement Officer Drugs Abuse dalam: Mardani, Penyalahgunaan Narkoba dalam Perspektif Hukum Islam dan Hukum Pidana Nasional, RajaGrafindo Persada, Jakarta.

Abdul Mun'im Idris et al, 1985, Ilmu Kedokteran Kehakiman, cetakan ke-II, Gunung Agung, Jakarta.

A.W., Widjaya, 1985, Masalah Kenakalan Remaja dan Penyalahgunaan Narkotika, Armico, Bandung.

Jurnal

I Nyoman Nurjaya, 2005, Penanggulangan Kejahatan Narkotika Perspektif Sosiologi Hukum, Legality Jurnal Ilmiah Hukum, Volume 13 No. 1, Maret-Agustus.

\section{Makalah}

Totok Yuliyanto, Pengurus PBHI Nasional dalam dialog satu tahun pelaksanaan UU No 35 Tahun 2009 tentang Narkotika dan UU No 36 Tahun 2009 tentang Kesehatan dalam Upaya Pencegahan dan Penanggulangan HIV dan AIDS di Indonesia. 


\section{Peraturan Perundang-undangan}

Undang-Undang Dasar Negara Republik Indonesia Tahun 1945.

Kitab Undang-undang Hukum Pidana.

Undang-undang Nomor 8 Tahun 1981 tentang Hukum Acara Pidana.

Undang-undang Nomor 12 Tahun 1995 tentang Pemasyarakatan.

Undang-undang Nomor 35 Tahun 2009 tentang Narkotika.

Undang-undang Nomor 5 Tahun 1997 tentang Psikotropika.

$\begin{array}{ccr}\text { Peraturan Pemerintah } & \text { No. } 31 & \text { Tahun } \\ 1999 \text { tentang } & \text { Pembinaan dan } \\ \text { Pembimbingan } & \text { Warga } & \text { Binaan } \\ \text { Pemasyarakatan. } & & \end{array}$

Surat Edaran Mahkamah Agung No 04 Tahun 2010 tentang Penetapan Penyalahgunaan, Korban Penyalahgunaan, dan Pecandu Narkotika ke dalam Lembaga Rehabilitasi Medis dan Rehabilitasi Sosial.

\section{Naskah Internet}

Lilik Mulyadi, Pemidanaan terhadap Pengedar dan Pengguna Narkoba, Penelitian Asas, Teori, Norma dan Praktik Penerapannya Dalam Putusan Pengadilan, Bab III, http://www. jaringnews.com/politik-peristiwa/ umum/43615/kepala-bnn-tahanannarkoba-membludak-lantaran-hakimtak-terapkan-uu-narkotika. 